\title{
Evaluation of egg replacers in a yellow cake system
}

\author{
D. Kohrs ${ }^{1}$, T. J. Herald ${ }^{3}$, F.M. Aramouni ${ }^{1}$, and M. Abughoush ${ }^{2 *}$ \\ ${ }^{1}$ Food Science Institute, Department of Animal Science and Industry, Kansas State \\ University, Manhattan, KS 66506, USA; ${ }^{2}$ Clinical Nutrition and Dietetics, The Hashemite \\ University, Zarqa 13133; ${ }^{3}$ USDA-Grain Marketing and Production Research Center, \\ Manhattan, KS, 66502, USA
}

\begin{abstract}
The egg alternatives (replacers) were used to replace egg as a functional ingredient in yellow cake system productions. Egg replacers were substituted at the levels of $50 \%$ and $100 \%$ of the dried whole eggs in the yellow cake system. The egg replacers were composed of whey protein isolate, wheat starch, guar gum, xanthan gum or their blends. At $50 \%$ substitution, treatments performed closer to that of control compared to $100 \%$ substitution. The blends of guar/whey/starch (GPS) and xanthan/whey/starch (XPS) performed the best, having the closest volume and texture measurement compared to the control. A quantitative descriptive analysis (QDA) was performed on blends of GPS and XPS at 100\% replacement. Six attributes of cakecrust stickiness, crumb color, springiness, moistness, firmness, and egg flavor--were quantified by a panel. These treatments were competitive to the control across all attributes measured. In the consumer acceptability test, the XPS formulation was significantly higher in acceptability for all attributes to that of the control. These alternatives can deliver functionality at a lower cost and can be incorporated to produce a suitable yellow cake system, especially blends of guar/whey/starch (GPS) and xanthan/whey/starch (XPS). These results may help producers in formulating yellow cake system.
\end{abstract}

Key words: dried whole-egg, egg replacers, yellow cake, sensory analysis, texture analysis.

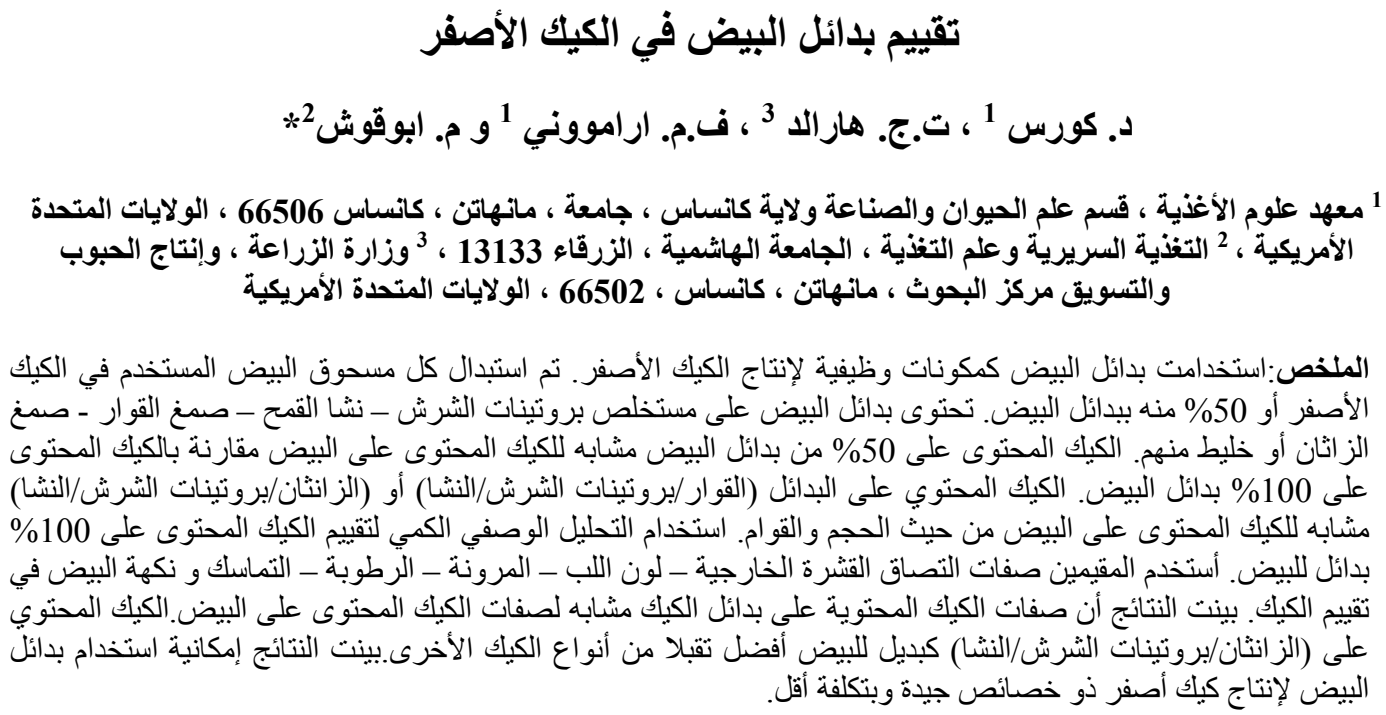

* Corresponding Author, Email: abulaith@hu.edu.jo 


\section{Introduction}

Eggs have high nutritional value and multi-functional properties, including emulsification, coagulation, foaming, and flavor (Yang and Baldwin, 1995). In the past, fresh eggs served as the primary ingredient for cakes made at home and in retail bakeries around the country (Pyler, 1988). As culture has changed over the last 100 years, the production of cakes moved from home and small retail bakeries to the widespread use of box mixes and large production facilities. Although egg's unique properties provide many advantages, a multitude of concerns from consumers and processors have led the baking industry to search for ingredients to replace eggs (Hard et al., 1963; Lin et al., 2003; Swaran et al., 2003). These concerns include a desire for low-cholesterol foods, reduced allergens, less expensive ingredients, increased shelf life, no refrigeration requirements, and fewer microbial concerns (Romanoff, 1949; Lin et al., 2003; Swaran et al., 2003)

Different egg replacers have been tried over the years to partially or completely replace eggs. Some of these egg replacers include: whey protein (Borstein and Bartov, 1966; Vitti, 1981; Arunepanlop et al., 1996; Swaran et al., 2003) and gums (Miller and Setser, 1983; Dogra et al., 1989; Conrad et al., 1993; Miller and Hoseney, 1993; Mott et al., 1999). Much of the research completed is old and a substantial portion of the work did not include any sensory evaluation which is very essential in product development (Lawless and Heymann, 1999). Patino et al. (2007) indicated that the foaming capacity increases with increasing the sunflower protein concentration (SPI) and its hydrolysates in solution. Foams retain a higher amount of liquid, are denser, and the air cells are smaller when the protein concentration increases. The foam stability also increases with the amount of protein in solution. Ashwini et al. (2009) found that addition of some types of the hydrocolloids increased the overall quality of eggless cake with sodium stearoyl-2-lactylate (SSL) and the highest improvement was brought about by hydroxylpropyl methylcellulose (HPMC). Comparisons of the physical and sensory properties of several commercial egg alternatives in angel food cake formulation were studied (Abu-Ghoush et al., 2010).

With the advent of new technologies, many new food ingredients are being advertised. However, there is very little literature that compares these ingredients to eggs in a scientific study. The hypothesis of this study is that some commercial ingredients may be available to processors to emulate some of the functional characteristics of whole-egg and compete in all physical and sensory attributes in a yellow cake system. Therefore, the objective of the study was to evaluate and compare the physical and sensory characteristics of egg replacers to dried whole egg in a yellow cake.

\section{Materials and Methods \\ Yellow cake preparation}

The ingredients used in all yellow cake formulations included iodized salt (Kroger Co., Cincinnati, OH), pure cane sugar (C\&H Sugar Co., Crockett, CA), and corn oil (Kroger Co., Cincinnati, $\mathrm{OH}$ ). The egg and egg substitutes evaluated in the yellow cake formula were either donated or purchased; including dry whole egg (Cutler Egg Products, Abbeville, AL), wheat starch (MGP Ingredients, Atchison, $\mathrm{KS}$ ), xanthan and guar gum (PB-S-GSP) (TIC Gum, Belcamp, MD), and whey protein isolate (WPI) (Davisco International, Eden Prairie, MN).

Cake batters were made according to the formula and method described in the AIB standard procedure for cake (American Institute of Baking, 1996). Eight treatments and a control were analyzed (Table 1). Cakes were mixed in a Hobart A-200 12-quart mixer (Hobart Corp., Troy, OH). Four cakes from each 
treatment were made by pouring $400 \mathrm{~g}$ of batter into $20.32 \mathrm{~cm} \mathrm{(8} \mathrm{in)} \mathrm{diameter}$ circular cake pans. Cakes were baked in a Reed four-reel oven (Reed Oven Co., Kansas City, MO) at $176.7^{\circ} \mathrm{C}\left(350^{\circ} \mathrm{F}\right)$ for $30 \mathrm{~min}$. After baking, cakes were cooled for $10 \mathrm{~min}$. before being de-panned and cooled to ambient temperature. Once cakes were fully cooled, they were individually bagged in a polyethylene film bag until testing.

Table 1. Selected treatments for the study.

\begin{tabular}{ll}
\hline Treatment & \\
\hline Control & $18.2 \% *$ dry whole egg \\
WPI & $18.2 \%$ whey protein isolate \\
WS & $18.2 \%$ wheat starch \\
GS & $1 \%$ gum guar $/ 17.2 \%$ wheat starch \\
GP & $1 \%$ gum guar $/ 17.2 \%$ whey protein isolate \\
GPS & $1 \%$ gum guar $/ 8.6 \%$ whey protein isolate $/ 8.6 \%$ wheat starch \\
XS & $1 \%$ xanthan gum $/ 17.2 \%$ wheat starch \\
XP & $1 \%$ xanthan gum $/ 17.2 \%$ whey protein isolate \\
XPS & $1 \%$ xanthan gum $/ 8.6 \%$ whey protein isolate $/ 8.6 \%$ wheat starch
\end{tabular}

Percentage flour basis, percentages reflect $100 \%$ replacement of egg

\section{Cake volume, symmetry, and contour}

Cakes volume, symmetry, and contour indexes were determined one day after baking by AACC Baking Quality Method 10-91 (AACC, 2000). The cakes were sliced into halves. The index template was placed up against the cut edges of cakes, and the heights of designated positions B, C, and D were recorded (Figure 1). These recorded heights were used to compute volume, symmetry, and contour as instructed in AACC method 1091 (2000). Volume is computed by $\mathrm{B}+\mathrm{C}$ $+\mathrm{D}$, symmetry by $|\mathrm{B}-\mathrm{D}|$, and contour by $2 \mathrm{C}-\mathrm{B}-\mathrm{D}$. Measurements were then averaged. Contour and symmetry describe the flow and setting of the cake batter. Excessive contour and poor symmetry can be a sign of early or irregular setting of crumb structure. These typical characteristics can relate to poor and nonuniform cell structure of crumb.

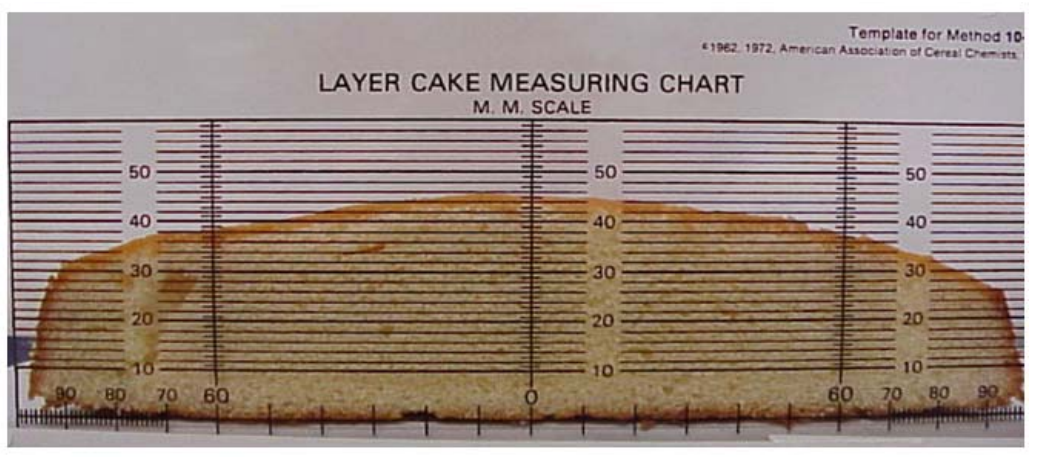

B

$\mathrm{C}$

D

Figure 1. American Association of Cereal Chemists template used to measure volume, contour, and symmetry. 


\section{Cake texture}

Texture of cake is most commonly found by using a compression test and measuring the strain. The strain force measurements, as well as other measurements, can be used to determine the hardness. A frequently used type of texture measurement is the texture profile analysis (TPA). The TPA imitates the mouth and palate, and can quantify texture characteristics of hardness, cohesiveness, springiness. The TPA is a technique using a two-cycle compression test, which imitates two bites. Texture was determined with TA-XT2 Texture Analyzer (Texture Technologies Scarsdale, NY) according to the AIB standard procedure for cake (American Institute of Baking, 1996). The $20.32 \mathrm{~cm}$ round cakes were sliced down the center, and two cuts were made $3.81 \mathrm{~cm}$ on either of the center slice. Cutout sections were placed on their side with the center cut face up, and were tested with a $2.54 \mathrm{~cm}$-diameter cylinder probe. Individual sections were probed in three different locations near the center of the pieces. This procedure was performed on two cakes per treatment per evaluation day, thus producing 12 measurements per treatment. The hardness and springiness of each measurement was recorded. Cakes were tested at 1 and $5 \mathrm{~d}$ after baking. Measurements on the texture analyzer used the following setting: test mode $\mathrm{T} P \mathrm{~A}$, pre-test speed $3 \mathrm{~mm} / \mathrm{s}$, test speed $1.7 \mathrm{~mm} / \mathrm{s}$, post-test speed $1.7 \mathrm{~mm} / \mathrm{s}$, distance $6 \mathrm{~mm}$, trigger auto at $20 \mathrm{~g}$, acquisition rate 200 pps.

\section{Cake color}

Crumb color was measured with a Hunter Miniscan portable colorimeter (HunterLab, Reston, VA). The colorimeter was calibrated by a light trap and white tile, according to procedure set forth by the Hunterlab owner's manual. Color was measured in natural light (C) at a $10^{\circ}$ angle. Three measurements of each sample were taken and then averaged. The $L$ value (lightness) was recorded and hue angle, $\left(\tan ^{-1} \mathrm{~b} / \mathrm{a}\right)$, was calculated to define crumb color (in the case of this study yellowness). Procedures for color were adapted from Lee et al. (1991).

\section{Quantitative descriptive analysis (QDA)}

Ten panelists ( 6 female and 4 male) were selected from Kansas State University and recruited to participate in the panel. Panelists were between the ages of 22 and 30, and all successfully completed the study.

Training was adapted from Archilla (2001). Panelists took part in three training sessions, each of which lasted approximately $1 \mathrm{~h}$. During training periods, panelists were introduced to testing procedures that allowed them to build skill and confidence to achieve valid and reliable results (Meilgaard et al., 1999). The QDA panelists were trained in a quiet room that was $23 \mathrm{C}$ and $50 \% \mathrm{RH}$. Panelists were asked to rate cakes based on six characteristics: crust stickiness, color, springiness, moistness, firmness, and egg flavor.

The group of panelists was trained on the first three cake attributes (crust stickiness, color, and springiness) in the first training session, whereas the other three attributes were presented in the second training session using scale from 115 point. Panelists were given attribute definitions and testing protocol. Reference samples for word anchors (Table 2) were presented to panelists during training to reduce variability and increase confidence. These references and definitions used in the QDA were adapted from earlier studies (Munoz, 1986; Bramesco, 1991; Lin et al., 2003). Panelists were presented samples that fell between reference samples in each category. The group then came to a consensus on where each sample fell between the reference anchors. The second training session was similar to the first, except that the last three attributes (moistness, firmness, and egg flavor) were presented. 
Table 2. Reference samples for sensory word anchors in descriptive analysis.

\begin{tabular}{lll}
\hline & \multicolumn{1}{c}{$\mathbf{0}$} & \multicolumn{1}{c}{$\mathbf{1 0}$} \\
\hline Surface Stickiness & White bread (not sticky) & fudge topping (very sticky) \\
Color & Paint sample "Rime (white) & paint sample "Yolk" (Yellow) \\
Springiness & Fudge brownie (no springiness) & polyethylene foam (very springy) \\
Moistness & Saltine cracker (very dry) & pound cake (very moist) \\
Firmness & Pound cake (very soft) & white cake w/egg white replaced \\
& & w/whey (very firm) \\
Egg Flavor & White bread (no Egg) & pound cake (very eggy)
\end{tabular}

In the third training session, all attributes were examined and reviewed by panelists. At the end of this training, a practice sensory test was performed to determine the consistency of the panel as a whole. Two different cake formulations were presented to panelists. Each cake sample consisted of a $24.58 \mathrm{~cm}^{3}$ cube of crumb and a $9.7 \mathrm{~cm}^{2}$ piece of cake crust, at ambient temperature. Samples were placed on a white paper plate with a three-digit code and were given to panelists along with a glass of distilled water, some napkins, and a list of reference anchors. Results were recorded on the sensory ballot by placing a vertical mark on a 5inch unstructured line. At the end of the practice sensory tests, each individual shared their approximate results with the group to compare consistency

To avoid sensory fatigue, the panelists evaluated only three cake formulations, a control (whole-egg), and two $100 \%$ replacement blends at a session (Harper et al., 1991; Lee and Resurreccion, 2004; Gallardo-Escamilla, et al., 2005). The blends were GPS (guar/whey protein isolate/wheat starch) and XPS (xanthan/whey protein isolate/wheat starch), which were selected because they showed the most potential in emulating the physical attributes of whole-egg in yellow cake. Each sample was again assigned a three-digit random code and was presented in a random order to each panelist. Two replications of the sensory test were performed over the course of $1 \mathrm{wk}$. Each testing session lasted approximately 15 min. Testing procedures, test location, and room environment were the same as during the practice test procedures performed in session three. Sample presentation consisted of three $24.58 \mathrm{~cm}^{3}$ cubes and a $9.7 \mathrm{~cm}^{2}$ piece of cake crust.

\section{Consumer acceptance test}

A total of 104 untrained consumers of both genders ( 57 females and 47 males) volunteered to participate in the acceptance test. Panelist ages ranged from 18 to 80 years old. All panelists were prescreened for food allergies and for how frequently they consumed cake. Consumer acceptance test procedure was adapted from Khouryieh (2003). This laboratory was equipped with white light and individual stations for evaluation. Each panelist evaluated two samples of cake during the session. One sample was the whole-egg control and the other sample was a $100 \%$ replacement of whole-egg with xanthan/whey protein isolate/wheat starch. The XPS was selected because this treatment possessed both the physical and QDA attributes that provided the highest probability of emulating the whole egg treatment. Both cake formulations had FD\&C Yellow \#5 added to batter to provide color to crumb. Added yellow color negated differences between crumb colors to prevent bias by consumers. Cake samples were served to panelists in 24.58 $\mathrm{cm}^{3}$ cubes on white paper plates at room temperature. Each sample was given a three-digit random number and samples were given to panelists in a random order. Sensory ballots, distilled water, and unsalted crackers were given along with 
cake samples. Panelists were instructed to cleanse mouth before tasting each sample. Cake was evaluated according to a 9-point hedonic scale to determine liking of product $(9=$ like extremely, $5=$ neither like nor dislike, $1=$ dislike extremely). The cake samples were evaluated on appearance, texture, flavor, and overall acceptability. For each cake, consumers were also asked if they would be willing to buy a product like this in stores.

\section{Statistics analysis}

Treatments were analyzed in a complete-block design. Three replications and two sub-samples per replication per day were performed for both a 50\% replacement group and 100\% replacement group. The experimental design included 11 different samples. For QDA, each mark was measured from the left end of the line scale. Marks were measured in inches and then converted to numbers by multiplying by 2 (i.e., $1 \mathrm{inch}=2$ ). This resulted in a 10-point scale for each attribute. Treatments were compared for each attribute. Statistical analysis was performed by using the Statistical Analysis System version 9.0 (SAS Institute, Inc.,
SAS Circle, Box 8000, Cary, NC). An analysis of variance (ANOVA) and least significant difference (LSD) comparisons were performed on all data. Significant differences between treatments were detected at a $\mathrm{p}<0.05$ level.

\section{Results and Discussion \\ Volume}

Data showed that a single ingredient egg replacer used at $100 \%$ substitution did not produce volumes significantly greater than the control cake (Figure 2). However, the addition of gums did result in significantly higher volume cakes. At $50 \%$ replacement, cake volume significantly improved compared to $100 \%$ replacement volumes. Only GP, GPS and XPS exhibited significantly $(p<0.05)$ greater volume than the control cake, however, GPS had a crumb with large holes and an open grain. Miller (1981) found that the addition of xanthan and wheat starch improved cakes with a reduced amount of eggs. Mott et al. (1999) found that adding xanthan gums to whey may increase foam stability. Pernell et al. (2002) found that adding xanthan may increase the volume of angel food cakes.

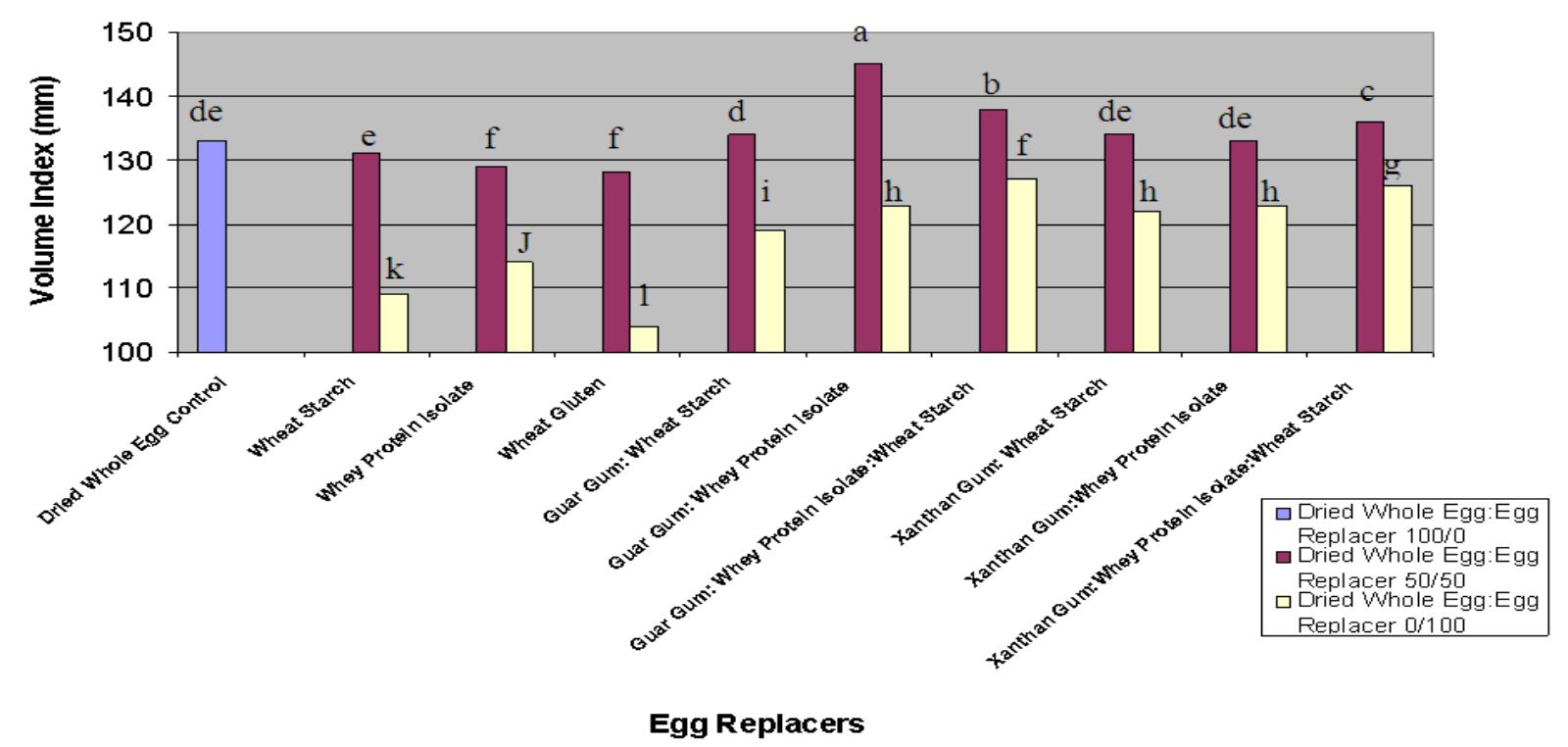

Figure 2. Comparison of volume index of yellow cake formulated with either dried whole egg or egg replacers. Means with different letters indicate significant differences among all treatments, $(p<0.05)$. 


\section{Contour}

Figure 3 exhibited contour indexes of cakes with ingredients used individually and in combination with either guar gum or xanthan gum. At 100\% substitution, WPI to mimic the contour of the wholeegg cakes. At $100 \%$ replacement of eggs with treatments containing GP and all the xanthan gum blends significantly improved the contour compared to the WS and WPI. Furthermore, GP, XS, XP and XPS exhibited a significantly higher contour compared with the control. At 50\% substitution the gum blends significantly decline except for the GP which improved over the $100 \%$ substitution compared to the control. Actually, there were no significant differences among different treatments regarding the symmetry found.

\section{Texture}

Texture was affected by replacing whole eggs with other ingredients. Hardness data showed that at $100 \%$ replacement, all treatments containing whey protein (WPI, GP, GPS, XP, and XPS) had significantly higher values, whereas those without whey protein (WS, GS, XS) were significantly less firm (Table 3). GPS and XPS were close to control in hardness value, but not statistically the same. When substitution was $50 \%$, hardness for all cake treatments decreased. All cake treatments increased in hardness from $\mathrm{d} 1$ to $\mathrm{d} 5$. At $\mathrm{d} 1$ and $100 \%$ substitution, GPS was the only egg replacers that exhibited a springiness value significantly greater than the control. GPS and WPI were significantly higher in springiness compared to the control at $\mathrm{d} 5$ (Table 4). At 50\% substitution, GPS exhibited a significantly higher springiness compared to the other egg replacers at $\mathrm{d} 1$. GP and XP were significantly greater in springiness than the other treatments at $\mathrm{d} 5$. These treatments decreased in springiness approximately $1 \%$ from $\mathrm{d} 1$ to $\mathrm{d} 5$.

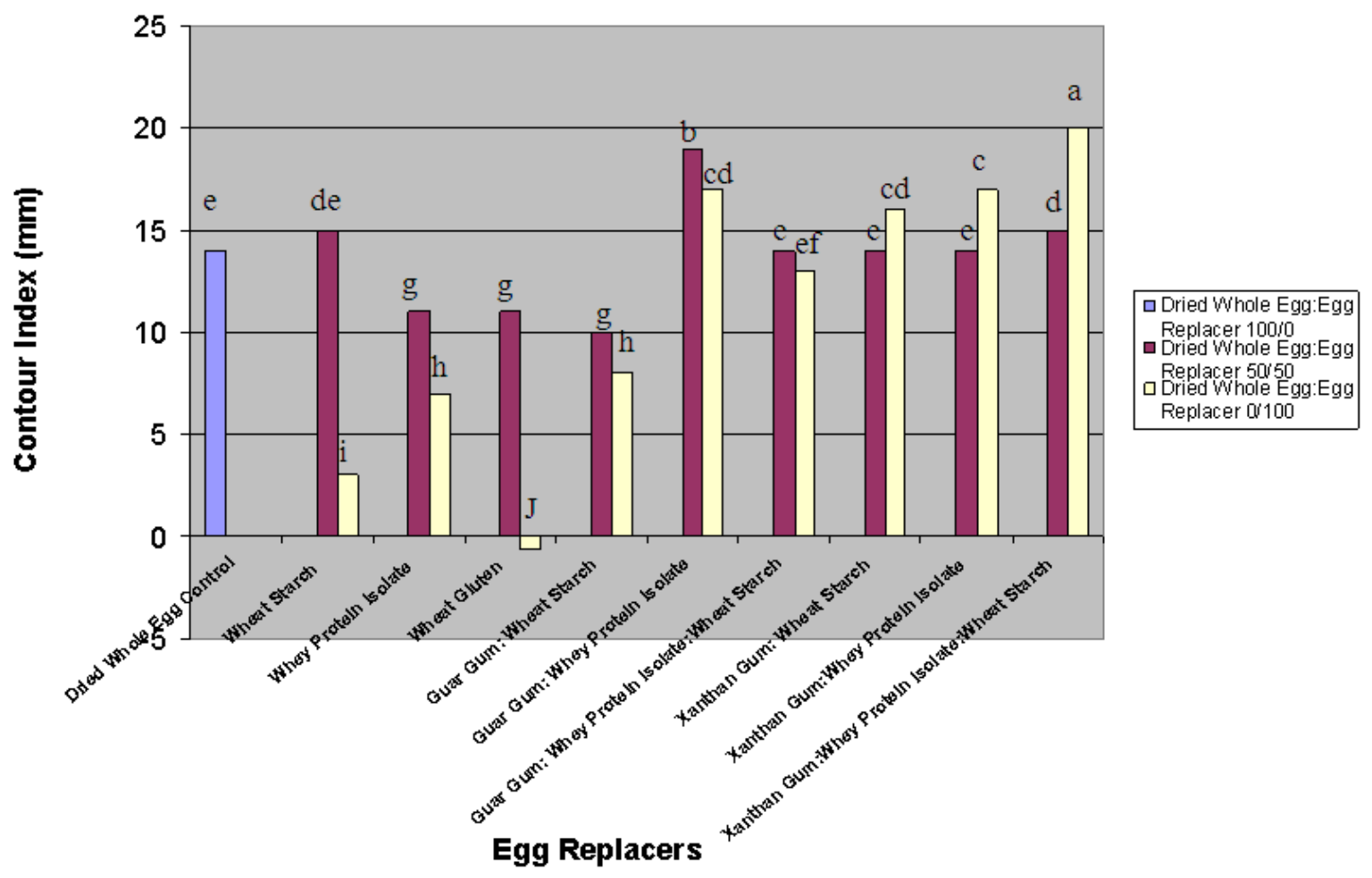

Figure 3. Comparison of contour index of yellow cake formulated with dried whole egg or egg replacers. Means with different letters indicate significant differences among all treatments, $(\mathbf{p}<0.05)$. 
Table 3.Comparison of the hardness of yellow cake formulated with either dried whole egg or selected replacers measured at day 1 and day 5 after baking by using textre analyzer.

\begin{tabular}{lllll}
\hline Treatments** $^{*}$ & $\begin{array}{l}\text { Day 1 } \\
\mathbf{1 0 0 : 0}\end{array}$ & $\mathbf{5 0 : 5 0}$ & $\begin{array}{l}\text { Day } \mathbf{5} \\
\mathbf{1 0 0 : 0}\end{array}$ & $\mathbf{5 0 : 5 0}$ \\
\hline Control & $295.33^{*}{ }^{\mathrm{f}}$ & & $400.80^{\mathrm{d}}$ & \\
WS & $261.15^{\mathrm{g}}$ & $230.43^{\mathrm{g}}$ & $363.23^{\mathrm{e}}$ & $311.25^{\mathrm{ef}}$ \\
WPI & $720.29^{\mathrm{a}}$ & $364.42^{\mathrm{b}}$ & $921.89^{\mathrm{a}}$ & $489.03^{\mathrm{bc}}$ \\
GS & $245.58^{\mathrm{h}}$ & $234.31^{\mathrm{fg}}$ & $332.26^{\mathrm{f}}$ & $344.66^{\mathrm{e}}$ \\
GP & $606.82^{\mathrm{c}}$ & $376.29^{\mathrm{b}}$ & $775.50^{\mathrm{b}}$ & $470.75^{\mathrm{c}}$ \\
GPS & $329.35^{\mathrm{e}}$ & $280.00^{\text {de }}$ & $450.12^{\mathrm{c}}$ & $395.75^{\mathrm{d}}$ \\
XS & $258.14^{\text {gh }}$ & $295.84^{\text {cd }}$ & $342.94^{\text {ef }}$ & $426.74^{\mathrm{d}}$ \\
XP & $618.03^{\mathrm{b}}$ & $446.43^{\mathrm{a}}$ & $795.43^{\mathrm{b}}$ & $556.95^{\mathrm{a}}$ \\
XPS & $355.06^{\mathrm{d}}$ & $314.41^{\mathrm{c}}$ & $470.66^{\mathrm{c}}$ & $415.50^{\mathrm{d}}$ \\
\hline
\end{tabular}

*Means with different superscripts in the same column indicate significant differences among all treatments, $(P \leq 0.05)$. ** Whey protein isolate (WPI), Wheat starch (WS), Guar gum/ wheat starch (GS), Guar gum/ whey protein isolate (GP), Guar gum/ whey protein isolate/ Wheat starch (GPS), Xanthan gum/ wheat starch (XS), Xanthan gum/ whey protein isolate (XP), Xanthan gum/ whey protein isolate/ Wheat starch (XPS).

Table 4. Comparison of the springiness of yellow cake formulated with either dried whole egg or selected replacers measured at day 1 and day 5 after baking by using textre analyzer.

\begin{tabular}{lllll}
\hline Treatments** & $\begin{array}{l}\text { Day 1 } \\
\mathbf{1 0 0 : 0}\end{array}$ & $\mathbf{5 0 : 5 0}$ & $\begin{array}{l}\text { Day 5 } \\
\mathbf{1 0 0 : 0}\end{array}$ & $\mathbf{5 0 : 5 0}$ \\
\hline Control & $0.945^{\text {b }}$ & & $0.896^{\text {cde }}$ & \\
WS & $0.934^{\mathrm{c}}$ & $0.930^{\mathrm{bcd}}$ & $0.901^{\mathrm{cde}}$ & $0.865^{\mathrm{d}}$ \\
WPI & $0.937^{\mathrm{c}}$ & $0.926^{\mathrm{de}}$ & $0.963^{\mathrm{ab}}$ & $0.896^{\mathrm{b}}$ \\
GS & $0.913^{\mathrm{d}}$ & $0.928^{\mathrm{cde}}$ & $0.836^{\mathrm{f}}$ & $0.884^{\mathrm{c}}$ \\
GP & $0.910^{\mathrm{de}}$ & $0.931^{\mathrm{bc}}$ & $0.921^{\mathrm{bcd}}$ & $0.920^{\mathrm{a}}$ \\
GPS & $0.970^{\mathrm{a}}$ & $0.941^{\mathrm{a}}$ & $0.977^{\mathrm{a}}$ & $0.896^{\mathrm{b}}$ \\
XS & $0.914^{\mathrm{d}}$ & $0.931^{\mathrm{bcd}}$ & $0.866^{\text {ef }}$ & $0.878^{\mathrm{c}}$ \\
XP & $0.907^{\mathrm{de}}$ & $0.920^{\mathrm{f}}$ & $0.898^{\text {cde }}$ & $0.919^{\mathrm{a}}$ \\
XPS & $0.945^{\mathrm{bc}}$ & $0.934^{\mathrm{b}}$ & $0.883^{\text {de }}$ & $0.881^{\mathrm{c}}$ \\
\hline
\end{tabular}

*Means with different superscripts in the same column indicate significant differences among all treatments, $(P \leq 0.05)$. ** Whey protein isolate (WPI), Wheat starch (WS), Guar gum/ wheat starch (GS), Guar gum/ whey protein isolate (GP), Guar gum/ whey protein isolate/ Wheat starch (GPS), Xanthan gum/ wheat starch (XS), Xanthan gum/ whey protein isolate (XP), Xanthan gum/ whey protein isolate/ Wheat starch (XPS).

\section{Color}

The $\mathrm{L}$ value for the control were significantly less (less light) than for all the egg replacers incorporated at $100 \%$ and $50 \%$ substitution at $\mathrm{d} 1$ and $\mathrm{d} 5$ (Table 5). A Hue angles for the control was significantly greater (more yellow) than all egg replacer at $100 \%$ and $50 \%$ substitution levels and for $\mathrm{d} 1$ and $\mathrm{d} 5$ (Table 6). There are no clear relationships between any treatment or added ingredient and the hue angle. 
Table 5. Comparison of the lightness (l) value of yellow cake formulated with either dried whole egg or selected replacers measured at day 1 and day 5 after baking by using a colorimeter.

\begin{tabular}{lllll}
\hline Treatments** & Day 1 & \multicolumn{3}{c}{ Day 5 } \\
\hline & $\mathbf{1 0 0 : 0}$ & $\mathbf{5 0 : 5 0}$ & $\mathbf{1 0 0 : 0}$ & $\mathbf{5 0 : 5 0}$ \\
\hline Control & $76.94^{\mathrm{f}}$ & & $76.29^{\mathrm{e}}$ & \\
WS & $80.35^{\mathrm{de}}$ & $81.58^{\mathrm{cd}}$ & $79.90^{\mathrm{cd}}$ & $80.05^{\mathrm{bc}}$ \\
WPI & $82.79^{\mathrm{abcd}}$ & $81.95^{\mathrm{bcd}}$ & $81.76^{\mathrm{abc}}$ & $81.21^{\mathrm{abc}}$ \\
GS & $80.65^{\mathrm{bcde}}$ & $81.21^{\mathrm{cd}}$ & $81.28^{\mathrm{abc}}$ & $80.00^{\mathrm{abc}}$ \\
GP & $84.68^{\mathrm{a}}$ & $83.92^{\mathrm{a}}$ & $83.57^{\mathrm{ab}}$ & $82.24^{\mathrm{a}}$ \\
GPS & $84.10^{\mathrm{ab}}$ & $81.13^{\mathrm{d}}$ & $83.28^{\mathrm{a}}$ & $80.77^{\mathrm{abc}}$ \\
XS & $80.33^{\mathrm{cde}}$ & $82.67^{\mathrm{abc}}$ & $81.04^{\mathrm{bcd}}$ & $81.05^{\mathrm{abc}}$ \\
XP & $84.61^{\mathrm{a}}$ & $82.14^{\mathrm{bcd}}$ & $84.12^{\mathrm{ab}}$ & $81.78^{\mathrm{ab}}$ \\
XPS & $83.71^{\mathrm{abc}}$ & $82.18 \mathrm{v}^{\mathrm{cd}}$ & $84.39^{\mathrm{ab}}$ & $80.24^{\mathrm{bc}}$ \\
\hline
\end{tabular}

* Means with different superscripts within the same column indicate significant differences among all treatments, $(P \leq 0.05)$. ** Whey protein isolate (WPI), Wheat starch (WS), Guar gum/ wheat starch (GS), Guar gum/ whey protein isolate (GP), Guar gum/ whey protein isolate/ Wheat starch (GPS), Xanthan gum/ wheat starch (XS), Xanthan gum/ whey protein isolate (XP), Xanthan gum/ whey protein isolate/ Wheat starch (XPS).

Table 6. Comparison of the hue angle $\left(\tan ^{-1} \mathrm{~b} / \mathrm{a}\right)$ color values of yellow cake formulated with either dried whole egg or selected egg replacers measured at day 1 and day 5 after baking by using a colorimeter.

\begin{tabular}{llllc}
\hline & Day 1 & & Day 5 \\
\hline & $\mathbf{1 0 0 : 0}$ & $\mathbf{5 0 : 5 0}$ & $\mathbf{1 0 0 : 0}$ & $\mathbf{5 0 : 5 0}$ \\
\hline CONTROL & $85.08^{\mathrm{a}}$ & $84.67^{\mathrm{a}}$ & $86.12^{\mathrm{a}}$ & $85.22^{\mathrm{a}}$ \\
WS & $83.32^{\mathrm{b}}$ & $83.10^{\mathrm{bcde}}$ & $83.95^{\mathrm{bc}}$ & $83.81^{\mathrm{bc}}$ \\
WPI & $79.97^{\mathrm{d}}$ & $82.52^{\text {ef }}$ & $80.52^{\mathrm{e}}$ & $83.30^{\mathrm{bcd}}$ \\
GS & $83.74^{\mathrm{b}}$ & $83.44^{\mathrm{b}}$ & $83.24^{\mathrm{c}}$ & $84.05^{\mathrm{b}}$ \\
GP & $79.52^{\mathrm{d}}$ & $81.99^{\mathrm{f}}$ & $80.11^{\mathrm{e}}$ & $82.29^{\mathrm{e}}$ \\
GPS & $80.93^{\mathrm{cd}}$ & $83.23^{\mathrm{bcd}}$ & $81.86^{\mathrm{d}}$ & $83.10^{\mathrm{cd}}$ \\
XS & $83.64^{\mathrm{b}}$ & $83.28^{\mathrm{bc}}$ & $84.39^{\mathrm{b}}$ & $83.89^{\mathrm{bc}}$ \\
XP & $79.44^{\mathrm{d}}$ & $82.65^{\mathrm{de}}$ & $79.87^{\mathrm{e}}$ & $82.60^{\mathrm{de}}$ \\
XPS & $81.77^{\mathrm{c}}$ & $82.89^{\mathrm{bcde}}$ & $81.85^{\mathrm{d}}$ & $83.43^{\mathrm{bc}}$ \\
\hline
\end{tabular}

* Means with different superscripts within the same column indicate significant differences among all treatments, $(P \leq 0.05)$. ** Whey protein isolate (WPI). Wheat starch (WS). Guar gum/ wheat starch (GS), Guar gum/ whey protein isolate (GP), Guar g D. Kohrs et al.

Xanthan gum/ wheat starch (XS), Xanthan gum/ wl protein isolate/ Wheat starch (XPS).

\section{Quantitative descriptive analysis (QDA)}

The QDA of cake attributes is shown in Table 7. Panelists reported that crust surface of cake variations containing xanthan and guar gums were stickier than that of the whole-egg control. Cake crust on GPS and XPS treatments in some instances actually adhered so firmly to fingers that the crust detached from crumb upon removing finger.
Cakes containing xanthan and guar gums have been found to produce sticky cakes (Villaudy et al., 1989). A similar phenomenon was found by Neville (1986), who reported that cakes with reduced foaming ability were gummy, with softer and stickier crusts. The stickiness /gumminess on the cake surface comes from the foam's instability and drainage of liquid (Mizukoshi, 1983a, b). A moisture 
gradient may exist that forms from drainage in cakes (Miller et al., 1967). This moisture most frequently accumulates at the bottom of cake (Mizukoshi, 1983a). The addition of gums may reduce moisture migration and gummy layers in cake (Miller et al., 1967) by holding excess water, thereby reducing foam instability (Miller, 1981). A small amount of moisture may have migrated to the crust, causing the sticky character.

Table 7. Quantitaive descriptive analysis by a trained panel of control, compared with two formulations of yellow cake without whole egg.

\begin{tabular}{lllllll}
\hline Treatments** & $\begin{array}{l}\text { Surface } \\
\text { stickiness* }\end{array}$ & $\begin{array}{l}\text { Crumb } \\
\text { yellowness }\end{array}$ & $\begin{array}{l}\text { Springine } \\
\text { ss }\end{array}$ & $\begin{array}{l}\text { Moistnes } \\
\text { s }\end{array}$ & $\begin{array}{l}\text { Firmnes } \\
\text { s }\end{array}$ & $\begin{array}{l}\text { Egg } \\
\text { favor }\end{array}$ \\
\hline CONTROL & $1.64^{\mathrm{b}}$ & $4.94^{\mathrm{a}}$ & $7.99^{\mathrm{a}}$ & $6.13^{\mathrm{b}}$ & $4.87^{\mathrm{a}}$ & $5.74^{\mathrm{a}}$ \\
XPS & $3.87^{\mathrm{a}}$ & $1.79^{\mathrm{b}}$ & $7.42^{\mathrm{ab}}$ & $6.60^{\mathrm{ab}}$ & $4.73^{\mathrm{a}}$ & $2.17^{\mathrm{b}}$ \\
GS & $3.65^{\mathrm{a}}$ & $2.02^{\mathrm{b}}$ & $7.18^{\mathrm{b}}$ & $6.90^{\mathrm{a}}$ & $3.97^{\mathrm{b}}$ & $2.28^{\mathrm{b}}$ \\
\hline
\end{tabular}

*Means with different superscripts in columns indicate significant difference $(P \leq 0.05) . * *$ Xanthan gum/ whey protein isolate/ Wheat starch (XPS), Guar gum/ wheat starch (GS).

Sensory data showed that the wholeegg control was significantly more yellow than both the XPS and GPS variations. The XPS and GPS did not contain any added colors to account for whole-egg xanthophyll content. Whole-egg control cakes exhibited higher springiness values than did XPS and GPS. Panelists found that XPS was not statistically different from the control, but GPS was different from control. The decrease in springiness may have been caused by the decreased foaming abilities of whey protein over that of dried whole egg. Lee et al. (1993) found that substitution of $25 \%$ or more of eggs caused a decrease in springiness.

Control cakes had lower moistness values than did XPS and GPS. Data showed that the whole-egg control was significantly less moist than GPS, but there was no difference in moisture between the control and XPS. Villaudy et al. (1989) reported that the addition of hydrocolloids increased moistness in chocolate cake. Increased moistness may be caused by foam drainage, causing excessive free water in cake. Differences between XPS and GPS may be due to the water-binding ability of xanthan, compared with guar.

Firmness of control was not significantly different than that of XPS. Treatment GPS was significantly different than both control and XPS. The decrease in firmness of GPS may have been caused by excess free water leading to gumminess. Egg flavor of whole-egg control cakes was significantly greater than the egg flavor of XPS and GPS treatments. Because variations contained no egg, this result was expected. This attribute was used more to gauge the ability of panelists and the effectiveness of training; panelists did report that XPS and GPS contained a small amount of egg flavor. This result may be caused by background flavors of vanilla and butter. The panel reported a slight off flavor in treatment with GPS. This flavor was characterized as "beany"; this may be a result of guar in the treatment. According to the ingredient sheet, guar may have a slight odor and flavor (TIC Gums, 2003).

\section{Consumer acceptance test}

One hundred and four consumers participated in the acceptance test. The prescreening data showed that the majority of consumers were between the ages of 18 and 25 and had completed at least some college, $56.7 \%$ and $54.8 \%$ respectively. Data showed that almost $75 \%$ of consumers consumed cake once every two weeks to once a month. Consumers found that the cake formula XPS was significantly more favorable than the whole-egg control cake in appearance, texture, flavor, and overall acceptability (Table 8). 
Emir. J. Food Agric. 2010. 22 (5): 340-352

http://ffa.uaeu.ac.ae/ejfa.shtml

Table 8. Consumer acceptance of control compared with formulation without whole- egg

\begin{tabular}{lllll}
\hline Treatments $^{* *}$ & Appearance* & Texture & Flavor & $\begin{array}{l}\text { Overall } \\
\text { acceptability }\end{array}$ \\
\hline CONTROL & $6.12^{\mathrm{b}}$ & $5.88^{\mathrm{b}}$ & $6.12^{\mathrm{b}}$ & $6.09^{\mathrm{b}}$ \\
XPS & $7.09^{\mathrm{a}}$ & $6.62^{\mathrm{a}}$ & $6.82^{\mathrm{a}}$ & $6.90^{\mathrm{a}}$ \\
\hline
\end{tabular}

* Means with different superscripts in columns indicate significant difference $(P \leq 0.05)$.

Hedonic Scale: 1- dislike extremely, 5- neither like nor dislike, 9- like extremely. ** Xanthan gum/ whey protein isolate/ Wheat starch (XPS).

Mean values of 104 consumer panelists indicated that the control was drier than the XPS formulation. Others stated that the control needed more flavor. Only $54 \%$ of consumer stated they would be willing to purchase the whole-egg control, whereas $70 \%$ stated they would purchase the XPS formulation.

\section{Conclusion}

The XPS cake was closest to control cake in firmness, springiness, and moistness, whereas, in the consumer acceptance test, replacement blend XPS had significantly higher ratings than did dry whole egg in cake appearance, texture, flavor, and overall acceptability. With the fast pace of changing technology in both processing technology and ingredient functionality, a competitive egg replacer may be available to processing in the near future.

\section{References}

AACC. 2000. Approved Methods of the American Association of Cereal Chemists. $10^{\text {th }}$ ed.

Abu-Ghoush, M., T. J. Herald, and F. Aramouni, 2010. Comparative Study of Egg White Protein and Egg Alternatives Used in an Angel Food Cake System. J. Food Process. Preserv. 34:411-425.

AIB. 1996. American Institute of Baking (AIB) Standard Methods. In: Anonymous.
Archilla, L. 2001. Evaluation of a maltodextrin gel as a partial replacement for fat in a high-ratio white-layer cake. J. Card Surg. 25:238-245.

Arunepanlop, B., C. V. Morr, D. Karleskind and I. Laye. 1996. Partial replacement of egg white proteins with whey proteins in angel food cakes. J. Food Sci. 61:1085-1093.

Ashwini, A. I,, R. Jyotsna and D. Indrani. 2009. Effect of hydrocolloids and emulsifiers on the rheological, microstructural and quality characteristics of eggless cake. Food Hydrocoll. 23:700-707.

Borstein, S. and I. Bartov. 1966. Studies on egg yolk pigmentation. Poult. Sci. 45:287.

Bramesco, N. P. 1991. Sensory and instrumental texture assessment of aerated bakery products: A consideration of salivation, salivary composition, flavor and time. Ph. D. dissertation, Kansas State University, USA.

Conrad, K. M., M. G. Mast, and J. H. Macneil. 1993. Effect of vacuum evaporation of liquid egg white on foaming properties. Poult. Sci. 72:1779-1788.

Dogra, R., M. A. Hill and R. Strange. 1989. The acceptability of three cake types incorporating varying levels of guar gum. Food Hydrocoll. 3:1-6. 
Gallardo-Escamilla, F. J., A . L. Kelly and C. M. Delahunty. 2005. Sensory characteristics and related volatile flavor compound profiles of different types of whey. J. Dairy Sci. 88:26892699.

Hard, M. M., J. V. Spencer, R. S. Locke, and M. H. George. 1963. A comparison of different shell eggs. 1. Effect on flavor. Poult. Sci. 42:815818.

Harper, S. J., D. L. Barnes, F. W. Bodyfelt and M. R. Mcdaniel. 1991. Sensory ratings of commercial plain yogurts by consumer and descriptive panels. J. Dairy Sci. 74:2927-2935.

Khouryieh, H. A. 2003. Evaluation of sucralose, maltodextrin and hydrocolloid gums in no sugaradded/low-fat muffin and sugar-free jelly. Ph. D. dissertation, Kansas State University, USA.

Lawless, H. T. and Heymann, H. 1999. Sensory Evaluation of Food: Principles and Practices. Aspen Publishers, Gaithersburg, MD.

Lee, C. C., J. A. Love and L. A. Johnson. 1993. Sensory and physical properties of cakes with bovine plasma products substituted for egg. Cereal Chem. 70:18-21.

Lee, C. C., L. A. Johnson, J. A. Love and S. Johnson. 1991. Effects of processing and usage level on performance of bovine plasma as an egg white substitute in cakes. Cereal Chem. 68:100-104.

Lee, C. M. and A. V. A. Resurreccion. 2004. Descriptive profiles of roasted peanuts stored at varying temperatures and humidity conditions. J. Sens. Stud. 19:433-459.
Lin, S. D., C. F. Hwang and C. H. Yeh. 2003. Physical and sensory characteristics of chiffon cake prepared with erythritol as replacement for sucrose. J. Food Sci. 68:2107-2110.

Meilgaard, M., G. V. Civille and B. T. Carr. 1999. Sensory Evaluation Techniques. 3rd ed. CRC Press, Boca Raton, Fla.

Miller, B. S., H. B. Trimbo and R. M. Sandstedt. 1967. The development of gummy layers in cakes. Food Technol. 21:377-380.

Miller, L. L. 1981. Addition of xanthan gum, wheat starch, and water to angel food cake with a reduced egg white level. $\mathrm{Ph}$. D. dissertation, Kansas State University, USA.

Miller, L. L. and C. Setser 1983. Xanthan gum in a reduced-egg-white angel food cake. Cereal Chem. 60:62-64.

Miller, R. A. and R. C. Hoseney. 1993. The role of xanthan gum in white layer cakes. Cereal Chem.70:585588.

Mizukoshi, M. 1983a. Model studies of cake baking. III. Effects of silicone on foam stability of cake batter. Cereal Chem. 60:396-399.

Mizukoshi, M. 1983b. Model studies of cake baking. IV. Foam drainage in cake batter. Cereal Chem. 60:399402.

Mott, C. L., N. S. Hettiarachchy and M. Oi. 1999. Effect of xanthan gum on enhancing the foaming properties of whey protein isolate. J . Amer. Oil Chem. Soc. 76(12):1383-1386. 
Munoz, A. M. 1986. Development and application of texture reference scales. J. Sens. Stud. 1:55-83.

Neville, N. E. 1986. Textural optimization of reduced-calorie layer cakes using polydextrose and a gum-emulsifier blend. Ph. D. dissertation, Kansas State University, USA.

Patino, R., C. Minones, L. Millan, J. Pedroche, S. Carrera, P. Victor and R. Millan. 2007. Interfacial and foaming properties of enzymeinduced hydrolysis of sunflower protein isolate. Food Hydrocoll. 21:782-793.

Pernell, C. W., P. J. Luck, E. A. Foegeding and C. R. Daubert. 2002. Heatinduced changes in angel food cakes containing egg-white protein or whey protein isolate. J. Food Sci. 67:29452951.

Pyler, E. J. 1988. Baking science \& technology. $3^{\text {rd }}$ ed. Merriam, Kan.: Sosland Pub. Co.

Romanoff, A. L. 1949. The avian egg. John Wiley \& Sons, New York
Swaran. S., G. S. Chauhan, R. Raghuvanshi, P. Sharma, O. P. Chauhan and Bajpai. 2003. Replacement of egg solids with whey protein concentrate and optimization of its levels in cake making. J. Food Sci. Technol. 40:386-388.

TIC Gums company. 2003. Guar 8/22 Ingredient Statement. Belcamp, MD, USA

Villaudy, B., S. E. Noelck and G. Tilly. 1989. Hydrocolloids in the microwavable chocolate cakes. In Anonymous FIE. Food ingredients Europe. Expoconsult Publishers, Maarssen, Netherlands.

Vitti, P. 1981. Whey and its use in breadmaking. Boletim do Instituto de Tecnologia de Alimentos, Brazil 18:167-176.

Yang, S. C. and R. E. Baldwin. 1995. Functional Properties of Eggs in Food. In: W. J. Stadelman and O. J. Cotterill (Eds). pp. 405-65. Eggs Science and Technology. Fourth ed. New York: The Hawworth Press. P. 